\title{
Investigation on Suitable Coating Material for Soy-lignin bonded Rhizophora spp. Particleboard for Medical Physics Applications
}

\author{
Siti Hajar Zuber, ${ }^{a}$ Nurul Ab. Aziz Hashikin, ${ }^{\mathrm{a}, *}$ Mohd Fahmi Mohd Yusof, ${ }^{\mathrm{b}}$ and \\ Rokiah Hashim ${ }^{\mathrm{c}}$
}

\begin{abstract}
A phantom material was prepared with different percentages of soy-lignin bonded with Rhizophora spp. particleboard and different coating materials, including epoxy resin, gloss wood finish, and a mixture of epoxy resin and gloss wood finish. A set of samples without coating was prepared for comparison. Each sample was bonded with $6 \%$ or $12 \%$ soylignin adhesives. The aim was to investigate the suitability of different coating materials at low energy range. The water absorption, thickness swelling, surface roughness, and mass attenuation coefficients of the samples with various coating materials were examined. Water absorption and thickness swelling of the samples coated with different coating materials followed a similar trend, but only one sample (coated with gloss wood finish) was within the recommended value of $12 \%$ according to JIS A 5908 (2003). Surface roughness testing revealed that the sample coated with gloss finish was smoother than other coated and non-coated samples. The mass attenuation coefficient of the sample coated with gloss finish was similar to that of water, indicating its suitability as a coating material for the Rhizophora spp. particleboard in medical physics applications.
\end{abstract}

Keywords: Particleboard; Rhizophora spp.; Coating material; Soy-lignin adhesive; Fabrication

Contact information: a: School of Physics, Universiti Sains Malaysia, 11800 Penang, Malaysia; $b$ : School of Health Sciences, Universiti Sains Malaysia, 15200 Kota Bharu, Kelantan, Malaysia; c: Division of Bioresource, Paper and Coatings Technology, School of Industrial Technology, Universiti Sains Malaysia, 11800 Penang, Malaysia; *Corresponding author: hashikin@usm.my

\section{INTRODUCTION}

Tissue-equivalent phantom material is an important tool for dosimetric applications in medical physics. The phantom can be manufactured in the shape of a human body or part of it, with density and radiation interactions similar to that of the actual human tissues (Ramos et al. 2017). Tissue substitute materials have been extensively used in experimental dosimetry (White et al. 1992). Tissue-equivalent phantom materials must be waterequivalent, as water is the most abundant component of the human soft tissue (Kienbock 1906; White and Constantinou 1982). Water has a mass density value close to that of muscle tissue, with similar radiation properties towards ionizing radiation.

Dosimetric wood-based phantoms have been used for many years, but the variable photon attenuation properties of wood are unclear (Braestrup and Blatz 1940). The linear attenuation coefficient is a physical quantity describing the attenuation properties of a material towards ionizing radiations. It is defined as the ratio between transmitted and initial photon intensities as the photon passes through a medium. This follows the BeerLambert's law, i.e., as photon passes through a medium, it is attenuated (Bouguer 1922). Estimation of the mass attenuation coefficient of material for medical physics application 
is not a trivial task. It encompasses the ability of ionising radiation to attenuate as it passes through different types of materials, thus depending on the characteristics of the material. The mass attenuation coefficient is also important in determining the penetration of photon through matter, as it considers the atomic composition of the attenuator.

Rhizophora spp. in the form of particleboards have been investigated for the fabrication of tissue-equivalent phantom (Sudin et al. 1988; Bradley et al. 1991; Marashdeh et al. 2011; Yusof et al. 2017a,b; Zuber et al. 2020). The physical and mechanical properties of phantoms for radiation studies have been improved by extensive research (Marashdeh et al. 2011; Abuarra et al. 2014; Tousi et al. 2014). The surfaces of the particleboard specimens are improved by making them smoother, which reduces the moisture content and allows uniform entrance of radiation with less scattering (van Meel et al. 2011). Different types of coating materials such as paint, epoxy resin, and gloss finish have been investigated previously (Nemli et al. 2005a; Norvydas and Minelga 2006; Rolleri and Roffael 2010; Nzokou et al. 2011; Dilik et al. 2015; Wang et al. 2018).

Epoxy-based materials are commercially available and can be used as coating and adhesive. Those used for surface coating are known to have superior properties, i.e., good mechanical and electrical insulation as well as good chemical and heat resistance. The most common types of epoxy resins are bisphenol A, bisphenol F, and phenoic novolac. Cured epoxy resin has outstanding chemical and corrosion resistance, excellent electrical insulation, high tensile, flexural, and compressive strengths, high thermal stability, and low shrinkage upon cure (Kroschwitz et al. 1991; Massingill Jr and Bauer 2000).

Gloss finish is a type of paint or solvent that gives glossy surface and a smooth mirror-like finish. Wood gloss finish provides excellent gloss and durability, great flexibility, and water resistance in all weather conditions. Previous research on the synthesis of polyacrylic resins in water-based coating showed that the coating retains the high gloss finish even under thermal stress (Saeed and Shabir 2013). However, the lowgloss powder coating hardens at lower temperatures (Lee et al. 2003). Thus, gloss finish improves the quality of particleboard, especially in terms of thermo-mechanical and archeological aspects (Vardi et al. 2010; Modrak and Mandulak 2013; Bekhta et al. 2014).

This study focused on the characterization of soy-lignin bonded Rhizophora spp. particleboard coated with different coating materials. Water absorption, thickness swelling, and surface roughness tests were performed. The linear and mass attenuation coefficients of the samples with different coating materials were measured. The coatings used in this study were epoxy resin and gloss wood finish, which are commonly used in the wood industry.

\section{EXPERIMENTAL}

\section{Materials}

Rhizophora spp. wood trunks were obtained from a coal factory in Kuala Sepetang. The trunk was cleaned, dried, debarked, ground, and sieved to produce samples with particle sizes of 0 to $103 \mu \mathrm{m}$. Slabs of particleboards bonded with different percentages of soy flour and lignin were constructed at a target density of $1.0 \mathrm{~g} \cdot \mathrm{cm}^{-3}$. Table 1 shows the manufacturing condition of the particleboards. 
Table 1. Particleboard Manufacturing Conditions

\begin{tabular}{|c|c|}
\hline Information & Condition \\
\hline Raw material & Rhizophora spp. \\
\hline Particleboard size & 0 to $103 \mu \mathrm{m}$ \\
\hline Target density & $1.0\left(\mathrm{~g} \cdot \mathrm{cm}^{-3}\right)$ \\
\hline Adhesives & Soy flour and lignin \\
\hline Hot pressing & Temperature: $200\left({ }^{\circ} \mathrm{C}\right) ;$ Time: 20 min; Pressure: $20 \mathrm{MPa}$ \\
\hline Coating material & $\begin{array}{c}\text { Epoxy resin; Gloss wood finish; Combination of epoxy resin and } \\
\text { gloss finish }\end{array}$ \\
\hline
\end{tabular}

The samples were prepared with dimensions of $5.0 \times 5.0 \times 0.5 \mathrm{~cm}^{3}$. Coating materials were epoxy resin (Type E-110I/H-9; Pan Asel Chemicals (M) Sdn Bhd Company, Kuala Lumpur, Malaysia) and gloss wood finish (Wood Finish Glossy D504-1005D; Kansai Paint, Klang, Selangor, Malaysia) obtained from the School of Industrial Technology, Universiti Sains Malaysia. All samples were prepared as shown in Table 2. The epoxy resin was prepared by mixing resin and hardener uniformly by weight with a ratio of 2:1. The sample was mixed and vigorously stirred using an electrical mixer (Pensonic PM-163 Hand Mixer; Pensonic Malaysia, Bukit Minyak, Penang, Malaysia). For samples coated with a combination of epoxy resin and gloss finish, the samples were coated with epoxy resin first and left for $24 \mathrm{~h}$ before further coating with gloss finish.

Table 2. Preparation of Rhizophora spp. Particleboard Samples With and Without Coating (the percentage of soy flour and lignin are relative to the dry weight of wood)

\begin{tabular}{|c|c|c|}
\hline Sample & Adhesive Percentage (\%) & Coating material \\
\hline $\mathrm{A}_{6}$ & $4.5 \%$ soy $+1.5 \%$ lignin & No coating \\
\hline $\mathrm{A}_{12}$ & $9 \%$ soy $+3 \%$ lignin & No coating \\
\hline $\mathrm{B}_{6}$ & $4.5 \%$ soy $+1.5 \%$ lignin & Epoxy resin \\
\hline $\mathrm{B}_{12}$ & $9 \%$ soy $+3 \%$ lignin & Epoxy resin \\
\hline $\mathrm{C}_{6}$ & $4.5 \%$ soy $+1.5 \%$ lignin & Epoxy resin + gloss wood finish \\
\hline $\mathrm{C}_{12}$ & $9 \%$ soy $+3 \%$ lignin & Gloss wood finish \\
\hline $\mathrm{D}_{6}$ & $4.5 \%$ soy $+1.5 \%$ lignin & Gloss wood finish \\
\hline $\mathrm{D}_{12}$ & 9 soy $+3 \%$ lignin & \\
\hline
\end{tabular}

\section{Methods}

Evaluation of linear and mass attenuation coefficients

The linear attenuation coefficient of the fabricated Rhizophora spp. particleboard was determined by using X-ray fluorescence (XRF) spectroscopy and spectroscopy amplifier (Ortec 572 Amplifier, Ortec Ametek; Advanced Measurement Technology, Tennessee, USA). The XRF method uses four basic components including radiation source, samples, radiation detector, and analyzing system. Pure metal plates were used to ensure measurement accuracy. Table 3 shows the properties of the metal plate targets (Hamid et al. 2017). The radiation source of Americium-241 $\left({ }^{241} \mathrm{Am}\right)$ with an activity of 3.7 GBq was used, and the experimental set up is displayed in Fig. 1. 
Table 3. Properties of Pure Metal Targets Used in this Study

\begin{tabular}{|c|c|c|c|c|}
\hline Metal plate & $\begin{array}{c}\text { Atomic Number } \\
(\mathrm{Z})\end{array}$ & Thickness (mm) & Purity (\%) & $\begin{array}{c}\text { Ka1 Energy } \\
(\mathrm{keV})\end{array}$ \\
\hline Niobium (Nb) & 41 & 0.14 & 99.8 & 16.61 \\
\hline $\begin{array}{c}\text { Molybdenum } \\
(\mathrm{Mo})\end{array}$ & 42 & 0.11 & 99.9 & 17.47 \\
\hline Palladium (Pd) & 46 & 0.10 & 99.9 & 21.17 \\
\hline Tin (Sn) & 50 & 0.28 & 99.999 & 25.27 \\
\hline
\end{tabular}

(Hamid et al. 2017)

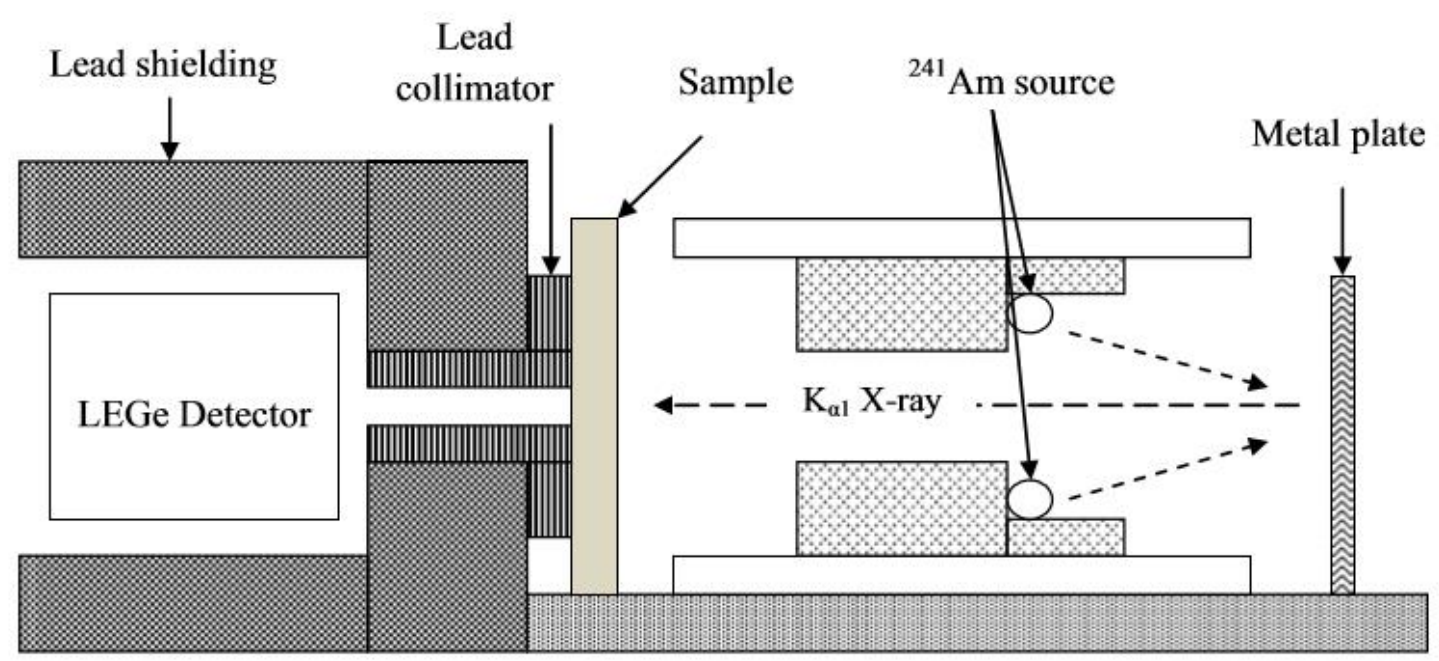

Fig. 1. The experimental set up for the XRF spectroscopy for the measurement of linear attenuation coefficients of Rhizophora spp. particleboard

Energy calibration was carried out with an LEGe detector using x-rays and gamma energies associated with ${ }^{241} \mathrm{Am}$ and characteristics $\mathrm{x}$-rays line of niobium, molybdenum, palladium, and tin metal plates. The ${ }^{241} \mathrm{Am}$ point source was placed at $5 \mathrm{~cm}$ distance from the LEGe detector. The energy resolution of the detector is calculated to determine the ability of the detector to produce narrow peaks in the spectrum. The energy resolution of the detector can be presented by full width half maximum (FWHM). The energy resolution, $\mathrm{R}$ is a dimensional fraction and conventionally expressed as a percentage calculated using Eq. 1,

$$
\text { Resolution, } R(\%)=\frac{F W H M}{E_{c}} \times 100 \%
$$

where FWHM is full width half maximum in $\mathrm{keV}$ and $E_{\mathrm{c}}$ is the energy at the centre of the peak in $\mathrm{keV}$.

The evaluation of the attenuation coefficient was based on the principle of x-ray fluorescent photon transmission, which penetrates through the sample with known thickness. Four samples of Rhizophora spp. particleboards bonded with $6 \%$ and $12 \%$ soylignin adhesives, with dimensions of $5.0 \times 5.0 \times 0.5 \mathrm{~cm}^{3}$ and average density equal to 1.0 $\mathrm{g} \cdot \mathrm{cm}^{-3}$ were placed at a distance of $9 \mathrm{~cm}$ from the metal plate and $7 \mathrm{~cm}$ from the detector and irradiated for $60 \mathrm{~s}$ each. The XRF spectrum obtained from the system was analyzed using MAESTRO software (MAESTRO-Pro Ortec Ametek; Advanced Measurement Technology, Tennessee, USA). The transmitted intensity was calculated by Eq. 2,

$$
I=I_{0} e^{-\mu x}
$$


where $I 0$ and $I$ are the initial photon and photon intensity, $\mu\left(\mathrm{cm}^{-1}\right)$ is the linear attenuation coefficient of the material, and $x$ is the thickness of the samples. Equation 3 shows the linear attenuation coefficient $\mu\left(\mathrm{cm}^{-1}\right)$ formulation.

$$
\mu=\frac{1}{x} \ln \left(\frac{I_{0}}{I}\right)
$$

The linear attenuation coefficient was determined by the average value of four readings, and the mass attenuation coefficient was calculated. The results were compared to the mass attenuation coefficient of water provided by XCOM software (NIST database; Gaithersburg, MD, USA), which is based on the elemental composition suggested by previous research (Constantinou et al. 1982; Berger and Hubbell 1987). A statistical analysis using a paired sample t-test was conducted to determine the correlation between the measured mass attenuation coefficient of each sample with the theoretical mass attenuation coefficient of water according to XCOM.

\section{Investigation on water absorption and thickness swelling}

Water absorption and thickness swelling test were carried out according to JIS A 5908 (2003) for particleboard to determine the dimensional stability of the test sample. The dimension of $5.0 \times 5.0 \times 0.5 \mathrm{~cm}^{3}$ test pieces were recorded including the thickness, length, and width using digital caliper pre- and post-immersion in water. The weight of each test piece was measured using an electronic balance. Each sample was immersed in distilled water at $3.0 \mathrm{~cm}$ below the water surface. After $24 \mathrm{~h}$, the test pieces were taken out, and excess water was wiped off. The thickness swelling and water absorption after the immersion were expressed in percentages as shown in Eqs. 4 and 5, respectively,

$$
\begin{aligned}
& \text { Thickness swelling }(\%)=\frac{t_{24}-t_{0}}{t_{0}} \times 100 \% \\
& \text { Water absorption }(\%)=\frac{W A_{24}-W A_{0}}{W_{0}} \times 100 \%
\end{aligned}
$$

where $t_{0}$ and $t_{24}$ are the average thickness before and after $24 \mathrm{~h}$ immersion in water, respectively, and $W A_{0}$ and $W A_{24}$ are the weights of the sample before and after $24 \mathrm{~h}$ immersion in water, respectively.

Investigation on the surface roughness of the particleboard with and without coating

Rhizophora spp. particleboards were prepared into $5.0 \times 5.0 \times 0.5 \mathrm{~cm}^{3}$ samples, which were classified into no coating sample, sample coated with gloss finish, sample coated with epoxy resin, and sample coated with both epoxy resin and gloss finish. All samples were conditioned at room temperature $\left(21^{\circ} \mathrm{C}\right)$. No sanding or other finishes were applied prior to and after coating, and no sanding was done before roughness measurements. The coatings were applied three times and left to dry for $24 \mathrm{~h}$. Thirty-two measurements were taken at measurement range of $\pm 400.00 \mu \mathrm{m}$, at measurement length of $4.0 \mathrm{~mm}$ with speed of $0.300 \mathrm{~mm} \cdot \mathrm{s}^{-1}$. A roughness profilometer (Surfcom 1800G S1400, Accretech, Tokyo Seimitsu, Tokyo, Japan) was calibrated at the calibration value of 0.960057, using a Gaussian type cutoff. Vertical displacement of the stylus is converted into electrical signal by a linear displacement of detector. The signals received were amplified and transferred into digital information (Hiziroglu et al. 2004). Standard roughness parameters obtained from the test include average roughness $\left(R_{\mathrm{a}}\right)$ and mean peak-to-valley height $\left(R_{\mathrm{z}}\right)$, which were calculated from the system. 


\section{RESULTS AND DISCUSSION}

\section{Linear and Mass Attenuation Coefficients}

The energy calibration of the XRF system was carried out using the LEGe detector set up for the measurement of mass attenuation coefficient by recording the mean count rate within a fixed range. The LEGe detector collected the XRF photons emitted from the metal plates, which were niobium (Nb), molybdenum (Mo), palladium (Pd), and tin ( $\mathrm{Sn}$ ). The energy calibration curve of LEGe detector for every peak energy was plotted. The best fit equation obtained was $y=0.0159 x-0.3109$, giving the conversion factor of 0.0159 $\mathrm{keV} /$ channel. The value of coefficient of determination from linear regression, $\mathrm{R}^{2}$, of the channel-energy calibration curve was 0.9999 , indicating excellent linearity between the photon energy and the channel of the XRF system measured by the LEGe detector.

Table 4 shows the energy resolution of LEGe detector at $K_{\mathrm{a} 1}$ energies of the metal plates. Figure 2 shows the energy calibration of the XRF systems at 16.61 to $25.27 \mathrm{keV} K_{\mathrm{s} 1}$ photon energy range and Fig. 3 shows the energy resolution calculated. The energy resolution was improved at increasing $K_{\mathrm{a} 1}$ energies, which was shown by the reduction of FWHM as shown in Table 4.

Table 4. The Energy Resolution of LEGe Detector within the Energy Range of $16.61 \mathrm{keV}$ to $25.27 \mathrm{keV}$

\begin{tabular}{|c|c|c|c|}
\hline Peak energy (keV) & Channel Number & FWHM (keV) & Energy Resolution (\%) \\
\hline 16.61 & 1069 & 29.39 & 2.7867 \\
\hline 17.47 & 1119 & 29.46 & 2.6623 \\
\hline 21.17 & 1357 & 31.88 & 2.3744 \\
\hline 25.27 & 1613 & 35.07 & 2.1891 \\
\hline
\end{tabular}

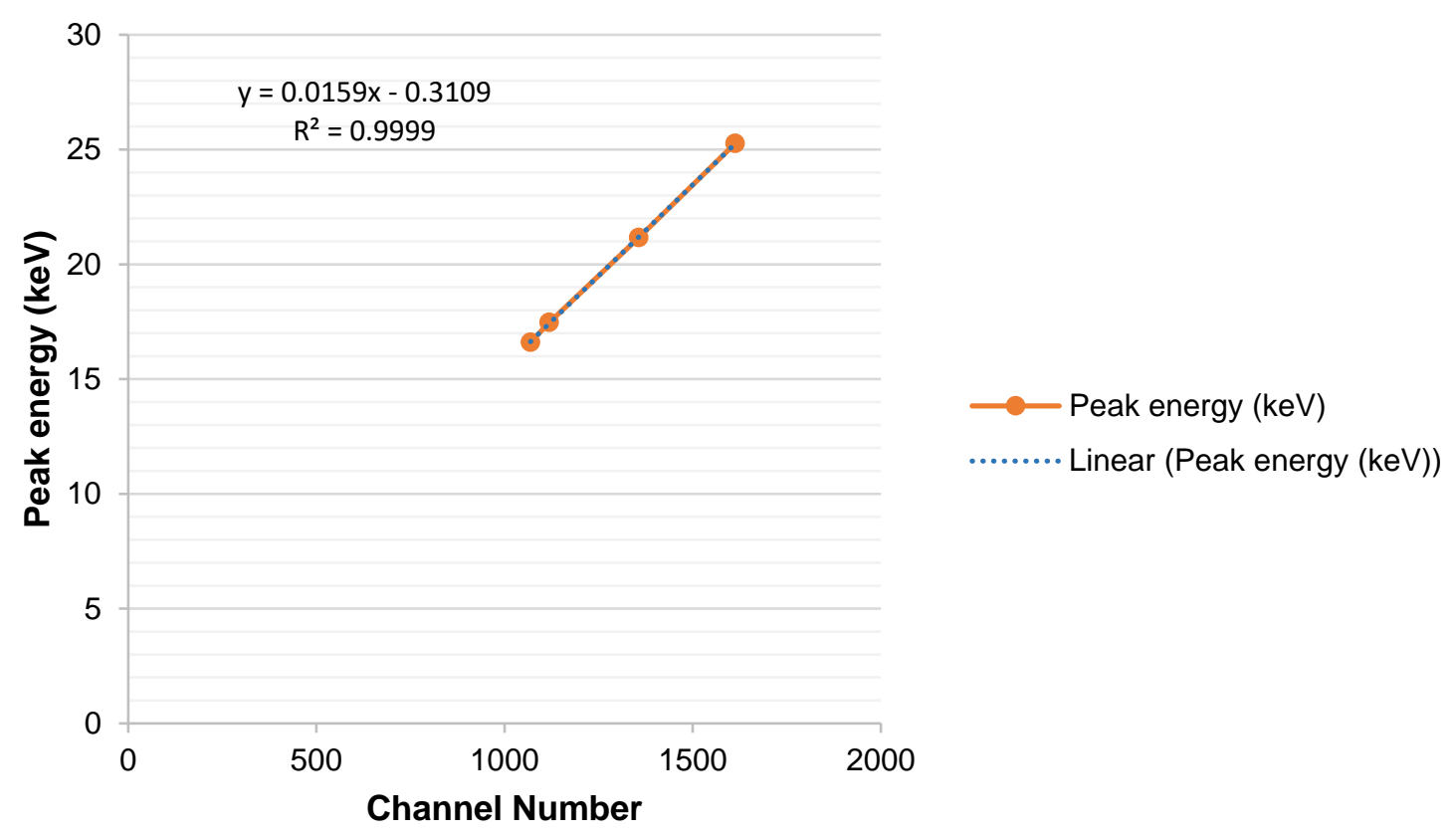

Fig. 2. Energy calibration of XRF at $16.61 \mathrm{keV}$ to $25.27 \mathrm{keV}$ 


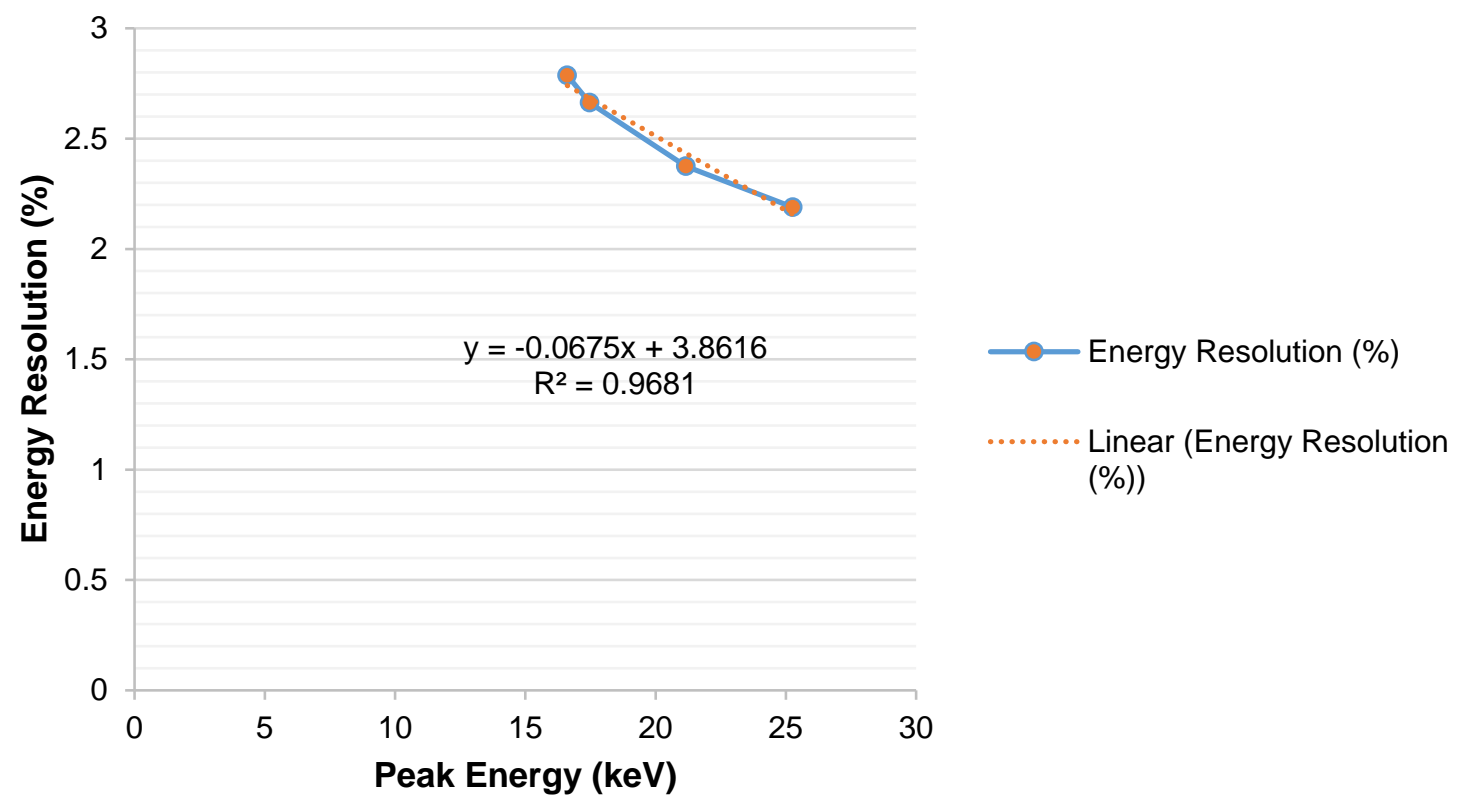

Fig. 3. The energy resolution for LEGe detector calculated

Table 5 shows the linear and mass attenuation coefficients of the fabricated Rhizophora spp. particleboard with different percentages of adhesives (6\% and 12\%) noncoated and coated with gloss finish, epoxy resin, and combination of gloss finish and epoxy resin, at low energy photons in comparison to water (XCOM). The mass attenuation coefficients of the samples are shown in Figs. 4, 5, 6, and 7.

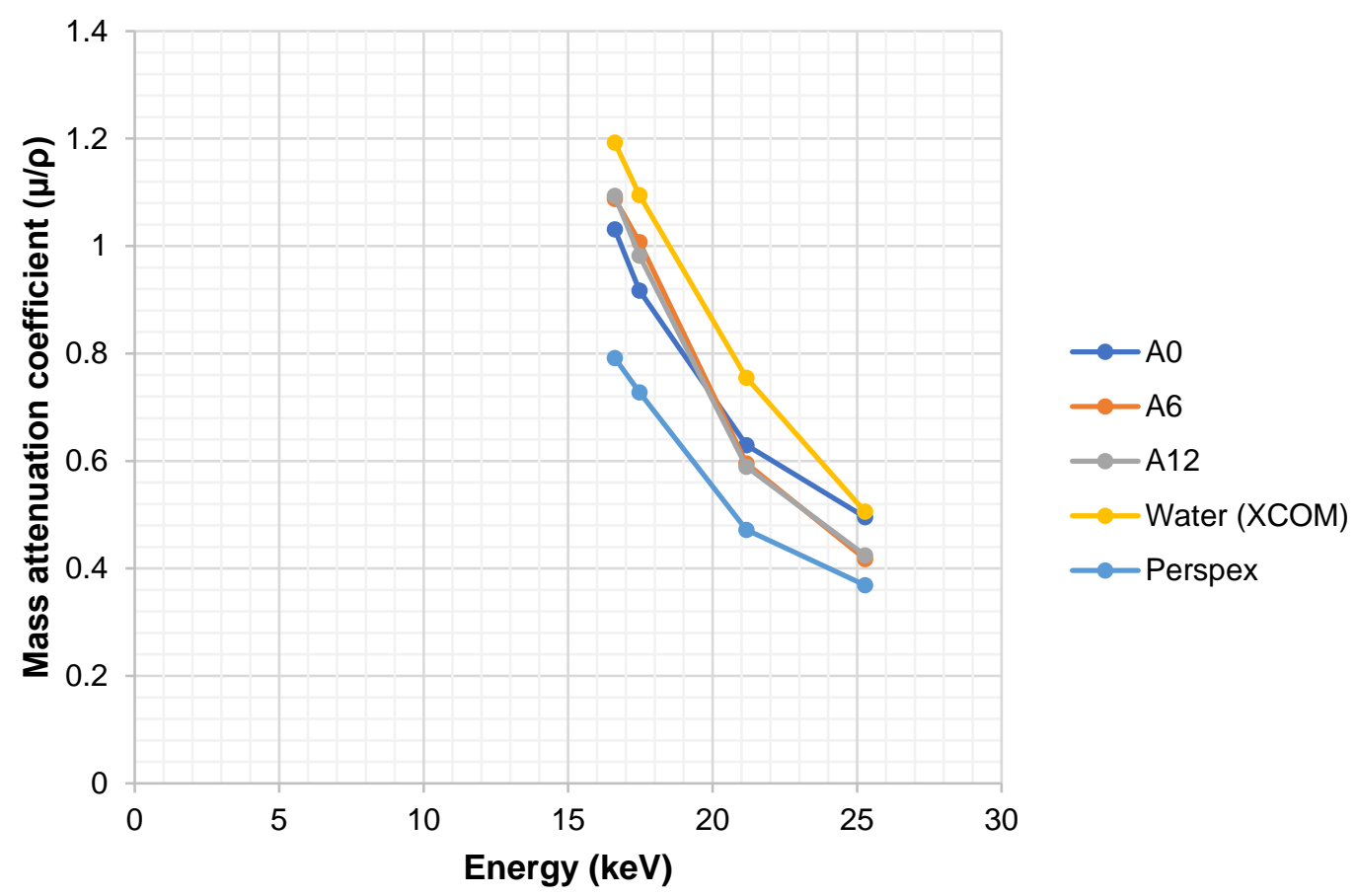

Fig. 4. The mass attenuation coefficients of Rhizophora spp. non-coated particleboards in comparison with water (XCOM) and Perspex at energy range of 16.62 to $25.27 \mathrm{keV}$ 
Table 5. Linear and Mass Attenuation Coefficients of the Fabricated Rhizophora spp. with Low Energy Photons in Comparison to Water (XCOM)

\begin{tabular}{|c|c|c|c|c|c|c|c|c|c|c|c|c|c|}
\hline \multirow{2}{*}{$\begin{array}{c}\text { Sample } \\
\text { Type }\end{array}$} & \multirow{2}{*}{$\begin{array}{l}\text { Average } \\
\text { Density } \\
\left(\mathrm{g} \mathrm{cm}^{-3}\right)\end{array}$} & \multicolumn{3}{|c|}{$\mathrm{Nb}(16.61 \mathrm{keV})$} & \multicolumn{3}{|c|}{ Mo (17.47 keV) } & \multicolumn{3}{|c|}{$\mathrm{Pd}(21.17 \mathrm{keV})$} & \multicolumn{3}{|c|}{$\mathrm{Sn}(25.27 \mathrm{keV})$} \\
\hline & & $\begin{array}{c}\mu \\
\left(\mathrm{cm}^{-1}\right)\end{array}$ & $\begin{array}{c}\mu / \rho \\
\left(\mathrm{cm}^{2} \mathrm{~g}^{-1}\right) \\
\end{array}$ & $\sigma_{\mu / \rho}$ & $\begin{array}{c}\mu \\
\left(\mathrm{cm}^{-1}\right)\end{array}$ & $\begin{array}{c}\mu / \rho \\
\left(\mathrm{cm}^{2} \mathrm{~g}^{-1}\right)\end{array}$ & $\sigma_{\mu / \rho}$ & $\begin{array}{c}\mu \\
\left(\mathrm{cm}^{-1}\right)\end{array}$ & $\begin{array}{c}\mu / \rho \\
\left(\mathrm{cm}^{2} \mathrm{~g}^{-1}\right)\end{array}$ & $\sigma_{\mu / \rho}$ & $\begin{array}{c}\mu \\
\left(\mathrm{cm}^{-1}\right)\end{array}$ & $\begin{array}{c}\mu / \rho \\
\left(\mathrm{cm}^{2} \mathrm{~g}^{-1}\right)\end{array}$ & $\sigma_{\mu / \rho}$ \\
\hline$A_{6}$ & 0.98 & 1.067 & 1.088 & 0.023 & 0.988 & 1.008 & 0.021 & 0.584 & 0.596 & 0.012 & 0.410 & 0.418 & 0.009 \\
\hline$A_{12}$ & 0.94 & 1.028 & 1.094 & 0.029 & 0.924 & 0.982 & 0.026 & 0.554 & 0.590 & 0.016 & 0.399 & 0.425 & 0.011 \\
\hline $\mathrm{B}_{6}$ & 0.91 & 0.903 & 0.988 & 0.018 & 0.871 & 0.953 & 0.017 & 0.531 & 0.581 & 0.010 & 0.392 & 0.428 & 0.008 \\
\hline $\mathrm{B}_{12}$ & 0.93 & 1.053 & 1.137 & 0.016 & 0.937 & 1.012 & 0.014 & 0.520 & 0.561 & 0.008 & 0.410 & 0.443 & 0.006 \\
\hline $\mathrm{C}_{6}$ & 0.97 & 0.944 & 0.971 & 0.016 & 0.912 & 0.938 & 0.016 & 0.540 & 0.556 & 0.009 & 0.421 & 0.433 & 0.007 \\
\hline $\mathrm{C}_{12}$ & 0.90 & 0.877 & 0.973 & 0.001 & 0.893 & 0.991 & 0.001 & 0.538 & 0.597 & 0.000 & 0.410 & 0.456 & 0.000 \\
\hline$D_{6}$ & 0.99 & 1.078 & 1.094 & 0.023 & 1.015 & 1.029 & 0.022 & 0.563 & 0.571 & 0.012 & 0.445 & 0.468 & 0.010 \\
\hline$D_{12}$ & 0.95 & 0.997 & 1.050 & 0.030 & 0.968 & 1.019 & 0.029 & 0.542 & 0.570 & 0.016 & 0.421 & 0.500 & 0.013 \\
\hline $\begin{array}{c}\text { Perspex } \\
\text { ( })\end{array}$ & 1.19 & 0.942 & 0.792 & 2.180 & 0.866 & 0.728 & 2.470 & 0.562 & 0.472 & 2.040 & 0.439 & 0.369 & 1.510 \\
\hline $\begin{array}{c}\text { Water } \\
\text { (XCOM) }\end{array}$ & 1.00 & 1.193 & 1.193 & - & 1.095 & 1.095 & - & 0.755 & 0.755 & - & 0.506 & 0.506 & - \\
\hline
\end{tabular}

A = No coating Rhizophora spp. sample; B = Sample coated with epoxy resin; C = Sample coated with gloss finish and epoxy resin; $D=$ Sample coated with gloss finish;

$0=0 \%$ soy flour \& lignin, $6=4.5 \%$ soy flour \& $1.5 \%$ lignin, $12=9 \%$ soy flour \& $3 \%$ lignin

Particle size used for all samples was $0-103 \mu \mathrm{m}$ 


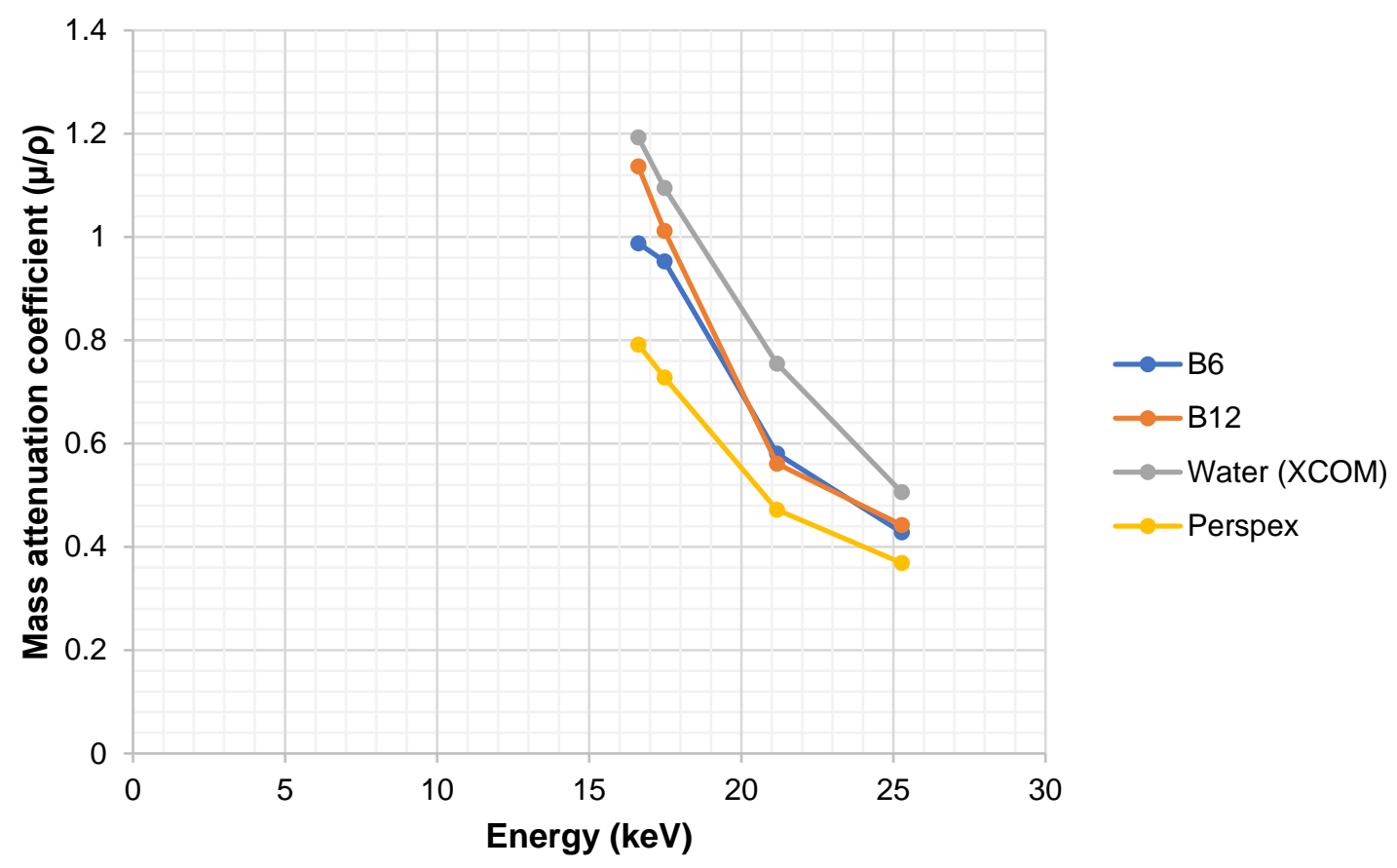

Fig. 5. The mass attenuation coefficients of Rhizophora spp. particleboards coated with epoxy resin in comparison with water (XCOM) and Perspex at energy range of 16.62 to $25.27 \mathrm{keV}$.

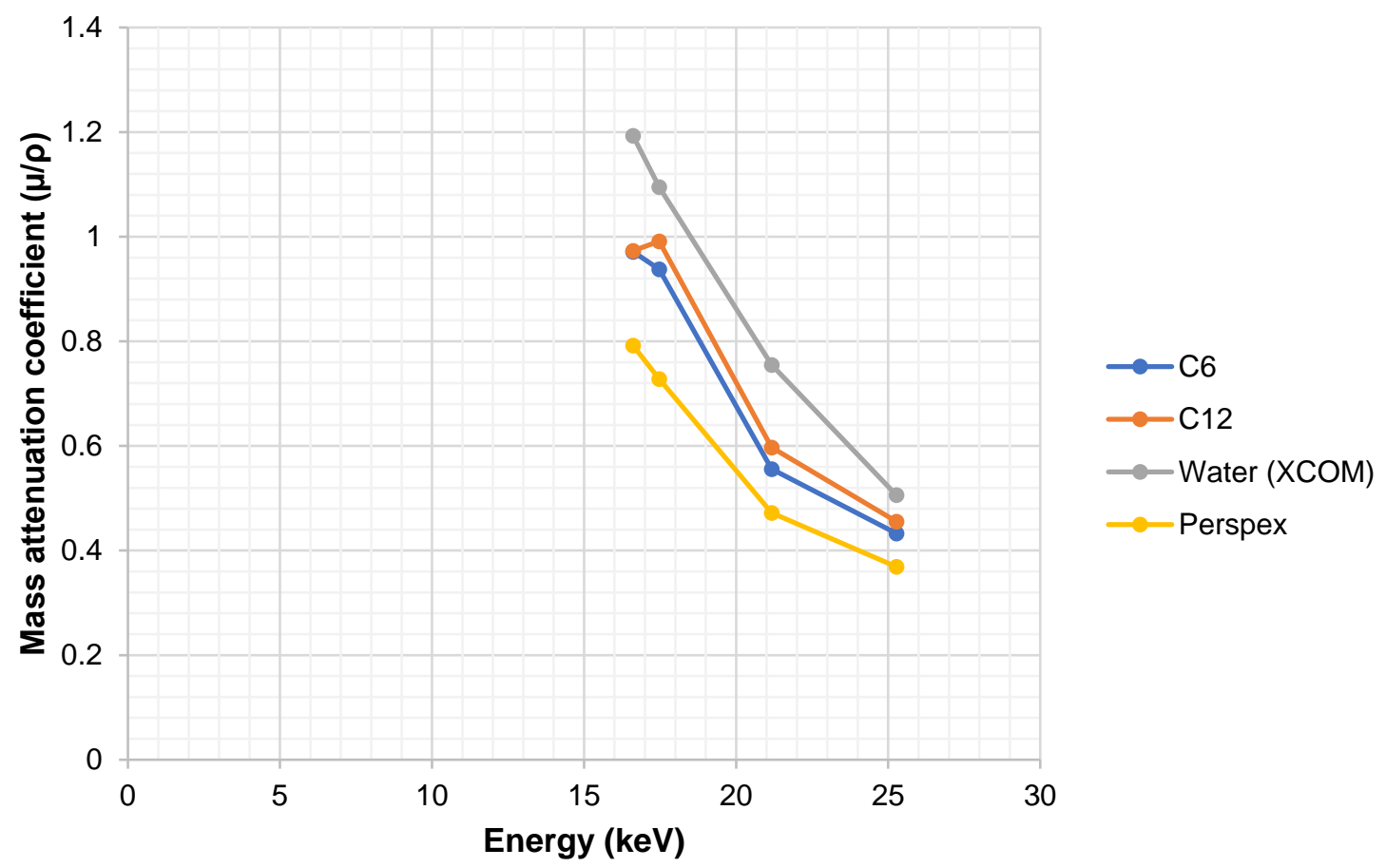

Fig. 6. The mass attenuation coefficients of Rhizophora spp. particleboards coated with combination of epoxy resin and glossy finish in comparison with water (XCOM) and Perspex at energy range of 16.62 to $25.27 \mathrm{keV}$. 
Table 6. Paired Sample t-test of the Mass Attenuation Coefficient of the Adhesive-bonded Rhizophora spp. With and Without Coating

\begin{tabular}{|c|c|c|c|c|c|c|c|}
\hline Sample & $\begin{array}{c}\text { Mean } \\
\text { Difference }\end{array}$ & $\begin{array}{c}\text { Standard } \\
\text { Deviation of } \\
\text { Difference }\end{array}$ & $\begin{array}{l}\text { Standard Error } \\
\text { of Difference }\end{array}$ & $\begin{array}{c}\text { T Alpha Half } \\
95 \% \mathrm{Cl}\end{array}$ & $\begin{array}{c}\text { Lower } \\
\text { Confidence } \\
\text { Level }\end{array}$ & $\begin{array}{c}\text { Upper } \\
\text { Confidence } \\
\text { Level }\end{array}$ & p-value \\
\hline $\mathrm{A}_{6}-\mathrm{XCOM}$ & 0.10990 & 0.03397 & 0.01699 & 3.182 & 0.05584 & 0.16396 & 0.007 \\
\hline $\mathrm{A}_{12}-\mathrm{XCOM}$ & 0.11460 & 0.03613 & 0.01807 & 3.182 & 0.05710 & 0.17210 & 0.008 \\
\hline $\mathrm{B}_{6}-\mathrm{XCOM}$ & 0.14975 & 0.05441 & 0.02720 & 3.182 & 0.06317 & 0.23633 & 0.012 \\
\hline $\mathrm{B}_{12}-\mathrm{XCOM}$ & 0.09915 & 0.06411 & 0.03206 & 3.182 & -0.00287 & 0.20117 & 0.054 \\
\hline $\mathrm{C}_{6}-\mathrm{XCOM}$ & 0.16275 & 0.06543 & 0.03272 & 3.182 & 0.05863 & 0.26687 & 0.016 \\
\hline $\mathrm{C}_{12}-\mathrm{XCOM}$ & 0.13295 & 0.07260 & 0.03630 & 3.182 & 0.01742 & 0.24848 & 0.035 \\
\hline $\mathrm{D}_{6}-\mathrm{XCOM}$ & 0.09668 & 0.06315 & 0.03158 & 3.182 & -0.00382 & 0.19717 & 0.055 \\
\hline $\mathrm{D}_{12}-\mathrm{XCOM}$ & 0.10235 & 0.07833 & 0.03916 & 3.182 & -0.02229 & 0.22699 & 0.079 \\
\hline
\end{tabular}

A = No coating Rhizophora spp. sample; B = Sample coated with epoxy resin; C = Sample coated with gloss finish and epoxy resin; $D=$ Sample coated with gloss finish;

$0=0 \%$ soy flour \& lignin, $6=4.5 \%$ soy flour \& $1.5 \%$ lignin, $12=9 \%$ soy flour \& $3 \%$ lignin

Particle size used for all samples was $0-103 \mu \mathrm{m}$ 


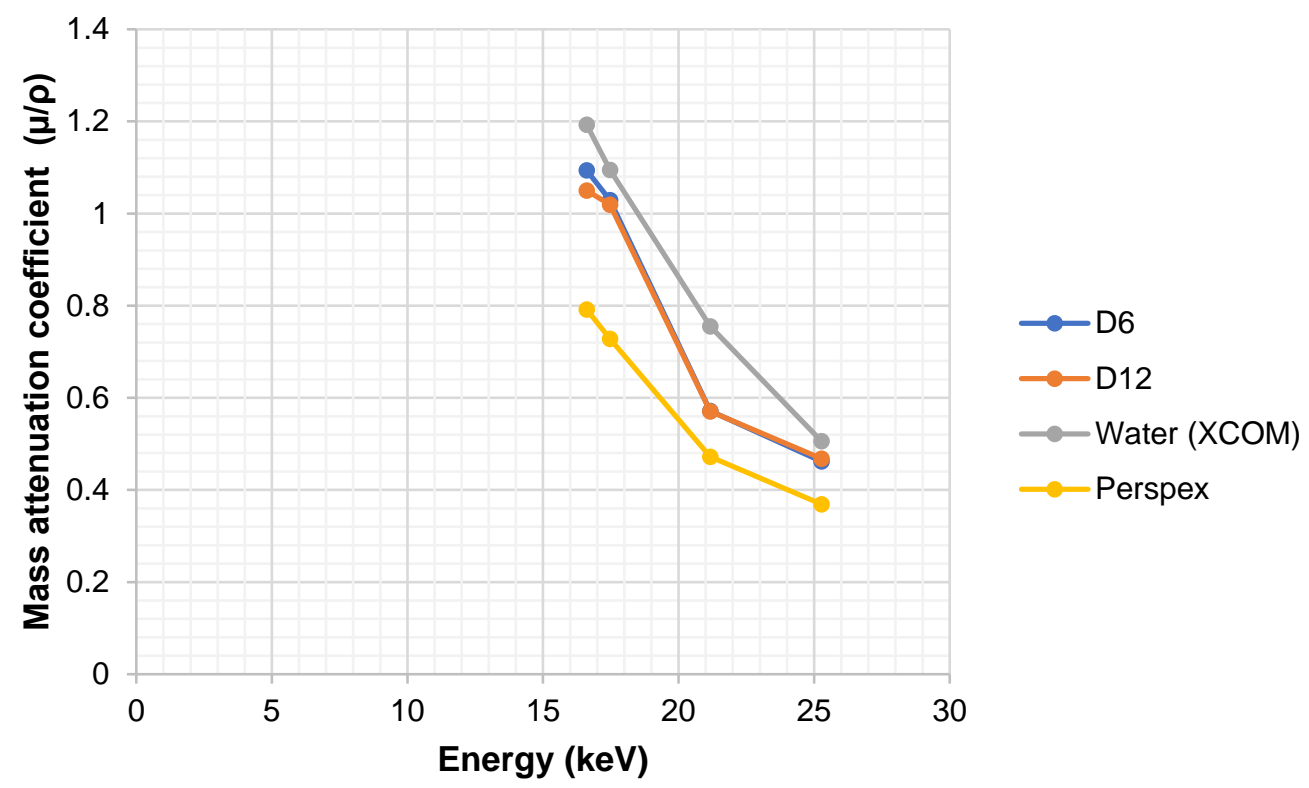

Fig. 7. The mass attenuation coefficients of Rhizophora spp. particleboards coated with glossy finish in comparison with water (XCOM) and Perspex at energy range of 16.62 to $25.27 \mathrm{keV}$.

Table 6 shows the paired sample t-test used to investigate the significant difference between the mass attenuation coefficient of the Rhizophora spp. particleboards samples and water from XCOM. The mass attenuation coefficients for samples D 6 and $\mathrm{D}_{12}(6 \%$ and $12 \%$ soy-lignin coated with gloss finish) did not have significant difference towards the mass attenuation coefficient of water, with p-value $>0.05$. However, the mass attenuation coefficients for other samples differed significantly with p-value less than 0.05 compared with water. This finding revealed the potential of gloss finish as a coating material for wood phantoms. Based on Figs. 4 to 7, the mass attenuation coefficients were close to that of water, which was similar to previous study (Marashdeh et al. 2012). This result revealed that the use of coating materials such as gloss finish did not interfere with the attenuation properties of the particleboard, thus confirming the potential of gloss finish as a suitable coating material.

\section{Analysis of Water Absorption and Thickness Swelling}

Water absorption and thickness swelling tests for all and coated and non-coated Rhizophora spp. particleboard samples are shown in Table 7. Samples D6 and D 12 (6\% and $12 \%$ soy-lignin bonded Rhizophora spp. particleboard coated with gloss finish) fulfilled the minimum requirement according to JIS A 5908 (2003) for thickness swelling (12\%), whereas the non-coated and other coated sample did not fulfill the minimum condition. Water absorption tests showed that $\mathrm{D}_{6}$ and $\mathrm{D}_{12}$ had relatively low values compared with the others, proving their resistance to moisture. The thickness swelling and water absorption test of the samples were greatly influenced by the coating materials, as similar particle size was used to fabricate all particleboards. The superior result for the sample coated with gloss finish could be due to its properties, which has excellent flow, gloss durability, flexibility, and water resistance in all weather conditions (Aznar et al. 2006). The result showed the suitability of gloss finish as potential coating material for the fabrication of tissueequivalent wood phantom; it allows only a small amount of water absorption compared with the other coating materials. 
Table 7. Water Absorption and Thickness Swelling Tests

\begin{tabular}{|c|c|c|c|c|}
\hline Sample & \multicolumn{2}{|c|}{ TS (\%) \pm Standard deviation } & \multicolumn{2}{c|}{ WA (\%) \pm Standard deviation } \\
\hline $\mathrm{A}_{6}$ & 29.88 & 2.46 & 69.77 & 3.14 \\
\hline $\mathrm{A}_{12}$ & 21.83 & 3.07 & 50.01 & 6.58 \\
\hline $\mathrm{B}_{6}$ & 14.96 & 1.55 & 57.19 & 1.35 \\
\hline $\mathrm{B}_{12}$ & 16.75 & 3.03 & 55.17 & 2.62 \\
\hline $\mathrm{C}_{6}$ & 14.79 & 3.25 & 47.66 & 1.55 \\
\hline $\mathrm{C}_{12}$ & 15.01 & 0.99 & 55.18 & 7.86 \\
\hline $\mathrm{D}_{6}$ & 12.77 & 0.49 & 46.43 & 0.64 \\
\hline $\mathrm{D}_{12}$ & 12.39 & 0.87 & 51.01 & 3.05 \\
\hline
\end{tabular}

$\mathrm{A}=$ No coating Rhizophora spp. sample; $\mathrm{B}=$ Sample coated with epoxy resin; C = Sample coated with gloss finish and epoxy resin; $\mathrm{D}=$ Sample coated with gloss finish;

$0=0 \%$ soy flour \& lignin, $6=4.5 \%$ soy flour \& $1.5 \%$ lignin, $12=9 \%$ soy flour $\& 3 \%$ lignin

Particle size used for all samples was $0-103 \mu \mathrm{m}$

\section{Measurement of the Surface Roughness}

The surface roughness results are presented in Table 8 .

Table 8. Surface Roughness Measurement

\begin{tabular}{|c|c|c|c|c|c|c|c|}
\hline $\begin{array}{l}\text { Sample } \\
\text { type }\end{array}$ & Samples & Mass (g) & Density $(\rho)$ & $R_{\mathrm{a}}(\mu \mathrm{m})$ & $\begin{array}{l}\text { Average } R_{a} \\
(\mu \mathrm{m})\end{array}$ & $R_{\mathrm{z}}(\mu \mathrm{m})$ & $\begin{array}{l}\text { Average } \\
R_{\mathrm{z}}(\mu \mathrm{m})\end{array}$ \\
\hline \multirow[t]{4}{*}{$A_{6}$} & $A$ & 10.06 & 0.82 & 5.62 & \multirow[t]{4}{*}{4.37} & 34.26 & \multirow[t]{4}{*}{26.33} \\
\hline & B & 10.15 & 0.84 & 6.34 & & 36.71 & \\
\hline & C & 10.21 & 0.84 & 3.06 & & 17.95 & \\
\hline & $\mathrm{D}$ & 12.16 & 0.95 & 2.47 & & 16.40 & \\
\hline \multirow[t]{4}{*}{$\mathrm{A}_{12}$} & $A$ & 9.80 & 0.80 & 4.02 & \multirow[t]{4}{*}{5.62} & 29.17 & \multirow[t]{4}{*}{32.18} \\
\hline & B & 9.71 & 0.79 & 3.60 & & 22.14 & \\
\hline & C & 9.46 & 0.80 & 6.05 & & 31.93 & \\
\hline & $\mathrm{D}$ & 9.41 & 0.81 & 8.80 & & 45.48 & \\
\hline \multirow[t]{4}{*}{$\mathrm{B}_{6}$} & $A$ & 12.41 & 0.96 & 3.74 & \multirow[t]{4}{*}{3.20} & 27.01 & \multirow[t]{4}{*}{22.23} \\
\hline & B & 12.16 & 0.95 & 2.21 & & 17.87 & \\
\hline & C & 11.20 & 0.90 & 2.83 & & 17.49 & \\
\hline & $\mathrm{D}$ & 10.87 & 0.85 & 4.04 & & 26.55 & \\
\hline \multirow[t]{4}{*}{$\mathrm{B}_{12}$} & $A$ & 11.95 & 0.90 & 8.10 & \multirow[t]{4}{*}{4.45} & 47.90 & \multirow[t]{4}{*}{27.57} \\
\hline & B & 12.99 & 0.97 & 1.82 & & 16.31 & \\
\hline & C & 12.23 & 0.92 & 2.51 & & 16.95 & \\
\hline & $\mathrm{D}$ & 10.60 & 0.91 & 5.38 & & 29.14 & \\
\hline \multirow[t]{4}{*}{$\mathrm{C}_{6}$} & $A$ & 13.80 & 1.04 & 2.69 & \multirow[t]{4}{*}{2.35} & 18.61 & \multirow[t]{4}{*}{16.88} \\
\hline & $B$ & 12.22 & 1.00 & 0.89 & & 4.69 & \\
\hline & C & 11.29 & 0.94 & 2.57 & & 19.17 & \\
\hline & $\mathrm{D}$ & 10.99 & 0.92 & 3.24 & & 25.05 & \\
\hline \multirow[t]{4}{*}{$\mathrm{C}_{12}$} & A & 10.20 & 0.90 & 3.35 & \multirow[t]{4}{*}{3.58} & 25.13 & \multirow[t]{4}{*}{24.53} \\
\hline & B & 10.12 & 0.90 & 3.13 & & 19.35 & \\
\hline & C & 9.93 & 0.90 & 3.55 & & 25.83 & \\
\hline & $D$ & 9.78 & 0.90 & 4.28 & & 27.81 & \\
\hline \multirow[t]{4}{*}{$D_{6}$} & $A$ & 13.03 & 1.04 & 1.62 & \multirow[t]{4}{*}{2.01} & 16.60 & \multirow[t]{4}{*}{15.95} \\
\hline & $B$ & 13.23 & 1.03 & 1.79 & & 13.19 & \\
\hline & C & 11.95 & 0.95 & 2.52 & & 18.18 & \\
\hline & $\mathrm{D}$ & 11.63 & 0.93 & 2.09 & & 15.82 & \\
\hline \multirow[t]{4}{*}{$D_{12}$} & $A$ & 12.90 & 1.00 & 1.99 & \multirow[t]{4}{*}{1.94} & 15.55 & \multirow[t]{4}{*}{15.75} \\
\hline & $B$ & 12.84 & 0.99 & 1.98 & & 15.37 & \\
\hline & C & 11.66 & 0.92 & 1.30 & & 9.71 & \\
\hline & $\mathrm{D}$ & 11.45 & 0.90 & 2.50 & & 22.37 & \\
\hline
\end{tabular}


The gloss-coated particleboards with $6 \%$ and $12 \%$ soy-lignin adhesives had the smoothest surface compared with the non-coated, epoxy-coated and gloss-epoxy-coated particleboards, with average $R_{\mathrm{a}}$ of $2.01 \mu \mathrm{m}$ and $1.94 \mu \mathrm{m}$, respectively. Figure 8 shows the typical roughness profile of the gloss-coated Rhizophora spp. particleboard.

This finding could be due to the coating material characteristic, which is shiny and mirror-like. The gloss surfaces are exceptionally smooth with only few microscopic irregularities to diffuse or spread light on an angular pattern. The high gloss of the coating is created by successive coats; increasing the number of coatings improves the coating thickness and reduces the surface roughness (Slabejova et al. 2016). The raw material used to fabricate particleboard also influences the surface roughness (Nemli et al. 2005b). The particleboard with 6\% soy-lignin adhesives showed lower surface roughness than particleboard with $12 \%$ soy-lignin adhesive for sample type A, B, and C, indicating that a higher amount of Rhizophora spp. particles reduce the surface roughness. A higher amount of raw Rhizophora spp. particles can be pressed easily during hot pressing with great compression ratio, leading to a tighter and more compact structure (Nemli et al. 2005b).

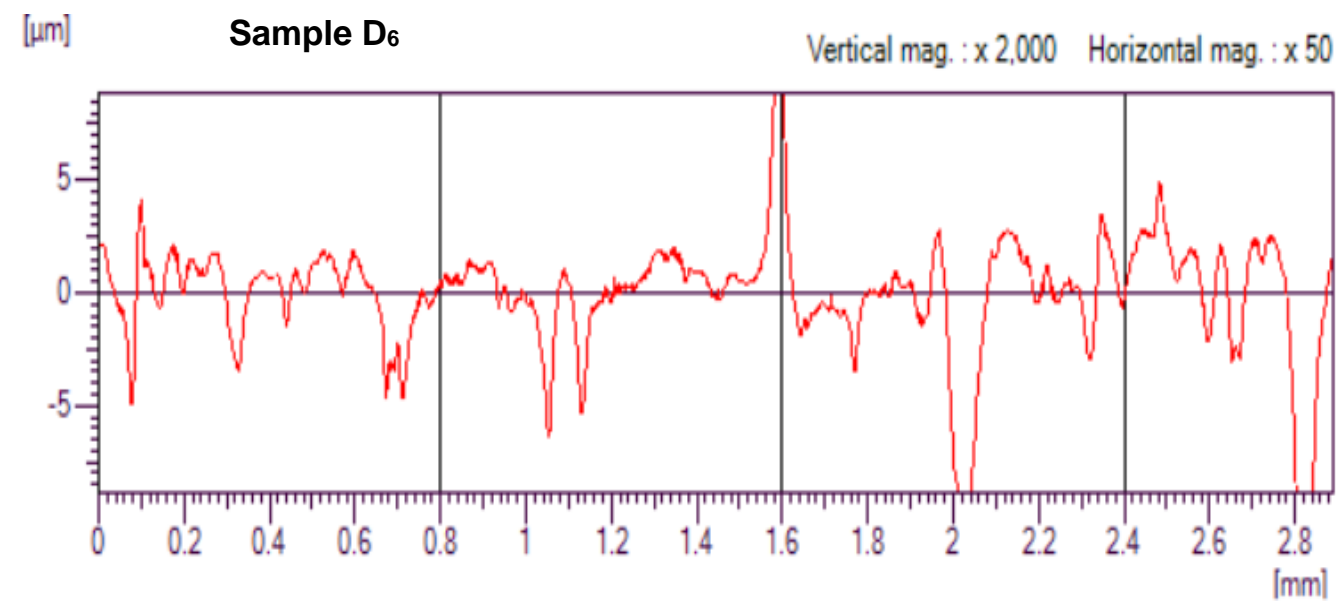

Fig. 8. Roughness profile of gloss-coated Rhizophora spp. particleboard for sample $\mathrm{D}_{6}$ (the linear peak energy is not visible due to device format that only capture predetermined vertical magnification)

\section{CONCLUSIONS}

1. Gloss finish can be used as coating for phantom materials made of particleboard for use in medical physics applications.

2. Gloss finish is within the recommended value of $12 \%$ according to JIS A 5908 (2003) for water absorption and thickness swelling tests.

3. Surface roughness testing revealed that the sample coated with gloss finish was the smoothest compared with the other coated and non-coated samples.

4. It is essential to account for mass attenuation coefficient of coated phantom material in the validation of its potential in dosimetry application. The mass attenuation coefficient calculated from XRF spectroscopy showed good agreement between the sample coated with gloss finish and water (XCOM). 


\section{ACKNOWLEDGMENTS}

The authors thank the School of Physics, School of Industrial Technology and Advanced Medical and Dental Institute, Universiti Sains Malaysia Malaysia for allowing this research to be conducted in the respective schools/institute. The authors also acknowledge the Universiti Sains Malaysia Short-Term Grant (304/PFIZIK/6315322), the School of Industrial Technology Grant (1001/PTEKIND/8014083), and the Universiti Sains Malaysia Bridging Grant (304.PPSK.6316324). The first author of this paper is financially sponsored by UTM Academic Fellow Scheme (SLAM) (2019-2021) and the author would like to thank UTMLead and Faculty of Science (Physics), Universiti Teknologi Malaysia, Johor for making this study possible. Kuala Sepetang supplied raw materials.

\section{REFERENCES CITED}

Abuarra, A., Hashim, R., Bauk, S., Kandaiya, S., and Tousi, E. T. (2014). "Fabrication and characterization of gum Arabic bonded Rhizophora spp. particleboards," Mater. Des. 60, 108-115. DOI: 10.1016/j.matdes.2014.03.032

Aznar, A. C., Pardini, O. R., and Amalvy, J. I. (2006). "Glossy topcoat exterior paint formulations using water-based polyurethane/acrylic hybrid binders," Prog. Org. Coatings 55, 43-49. DOI: 10.1016/j.porgcoat.2005.11.001

Bekhta, P., Proszyk, S., Lis, B., and Krystofiak, T. (2014). "Gloss of thermally densified alder (Alnus glutinosa Goertn.), beech (Fagus sylvatica L.), birch (Betula verrucosa Ehrh.), and pine (Pinus sylvestris L.) wood veneers," Eur. J. Wood Wood Prod. 72, 799-808. DOI: 10.1007/s00107-014-0843-3

Berger, M. J., and Hubbell, J. H. (1987). XCOM: Photon Cross Sections on a Personal Computer, National Bureau of Standards, Washington, DC. DOI: 10.2172/6016002

Bouguer, P. (1922). Essai d'Optique sur la Gradation de la Lumière. DOI: 10.1038/111320b0

Bradley, D. A., Tajuddin, A. A., Sudin, C. W. A. C. W., and Bauk, S. (1991). "Photon attenuation studies on tropical hardwoods," Int. J. Radiat. Appl. Instrumentation. Part A. Appl. Radiat. Isot. 42, 771-773. DOI: 10.1016/0883-2889(91)90182-Z

Braestrup, C. B., and Blatz, I. H. (1940). "Physical factors of low voltage "contact" roentgen therapy," Radiology 35, 198-205. DOI: 10.1148/35.2.198

Constantinou, C. (1982). "Phantom materials for radiation dosimetry," I. Liquids and gels. Br. J. Radiol. 55(651), 217-224. DOI: 10.1259/0007-1285-55-651-217

Dilik, T., Erdinler, S., Hazır, E., Koç, H., and Hiziroglu, S. (2015). "Adhesion strength of wood based composites coated with cellulosic and polyurethane paints," Adv. Mater. Sci. Eng. 2015, Article ID 745675. DOI: 10.1155/2015/745675

Hamid, P. N. K. A., Yusof, M. F. M., Tajuddin, A. A., and Hashim, R. (2017). "Measurement of mass attenuation coefficients for corn starch bonded Rhizophora spp. particleboards at 16.59-25.26 keV photons using X-ray fluorescence configuration," J. Sains Nukl. Malaysia 29, 44-51.

Hiziroglu, S., Jarusombuti, S., and Fueangvivat, V. (2004). "Surface characteristics of wood composites manufactured in Thailand," Build. Environ. 39, 1359-1364. DOI: 10.1016/j.buildenv.2004.02.004

JIS A 5908 (2003). "Particleboards," Japanese Standards Association, Tokyo, Japan. 
Kienbock, R. (1906). “On the quantimetric method,” Arch. Roentgen Ray 11, 17-20. DOI: 10.1259/arr.1906.0005

Kroschwitz, J. I. (1991). High Performance Polymers and Composites, Wiley, New York.

Lee, S. S., Koo, J. H., Lee, S. S., Chai, S. G., and Lim, J. C. (2003). "Gloss reduction in low temperature curable hybrid powder coatings," Prog. Org. coatings 46, 266-272. DOI: 10.1016/S0300-9440(02)00197-2

Marashdeh, M. W., Bauk, S., Tajuddin, A. A., and Hashim, R. (2012). "Measurement of mass attenuation coefficients of Rhizophora spp. binderless particleboards in the $16.59-25.26 \mathrm{keV}$ photon energy range and their density profile using x-ray computed tomography," Appl. Radiat. Isot. 70, 656-662. DOI: 10.1016/j.apradiso.2012.01.008

Marashdeh, M. W., Hashim, R., Tajuddin, A. A., Bauk, S., and Sulaiman, O. (2011). "Effect of particle size on the characterization of binderless particleboard made from Rhizophora spp. mangrove wood for use as phantom material," BioResources 6(4), 4028-4044. DOI: 10.15376/biores.6.4.4028-4044

Massingill Jr, J. L., and Bauer, R. S. (2000). "Epoxy resins," in: Applied Polymer Science: $21^{\text {st }}$ Century, C. D. Craver and C. E. Carraher, Jr. (eds.), Elsevier, Amsterdam, pp. 393-424.

Modrak, V., and Mandulak, J. (2013). "Exploration of impact of technological parameters on surface gloss of plastic parts," Procedia CIRP 12, 504-509. DOI: 10.1016/j.procir.2013.09.086

Nemli, G., Örs, Y., and Kalaycıŏlu, H. (2005a). "The choosing of suitable decorative surface coating material types for interior end use applications of particleboard," Constr. Build. Mater. 19(4), 307-312. DOI: 10.1016/j.conbuildmat.2004.07.015

Nemli, G., Ozturk, I., and Aydin, I. (2005b). "Some of the parameters influencing surface roughness of particleboard," Build. Environ. 40(10), 1337-1340. DOI: 10.1016/j.buildenv.2004.12.008

Norvydas, V., and Minelga, D. (2006). "Strength and stiffness properties of furniture panels covered with different coatings," Mater. Sci. 12, 328-332.

Nzokou, P., Kamdem, D. P., and Temiz, A. (2011). "Effect of accelerated weathering on discoloration and roughness of finished ash wood surfaces in comparison with red oak and hard maple," Prog. Org. Coatings 71(4), 350-354. DOI: 10.1016/j.porgcoat.2011.03.028

Ramos, S. M. O., Thomas, S., Berdeguez, M. B. T., Sá, L. V, and Souza, S. A. L. (2017). "Anthropomorphic phantoms - Potential for more studies and training in radiology," Int. J. Radiol. Radiat. Ther. 2(4), 101-104. DOI: 10.15406/ijrrt.2017.02.00033

Rolleri, A., and Roffael, E. (2010). "Influence of the surface roughness of particleboards and their performance towards coating," Maderas. Cienc. y Tecnol. 12(2), 143-148. DOI: $10.4067 / \mathrm{S} 0718-221 \mathrm{X} 2010000200009$

Saeed, A., and Shabir, G. (2013). "Synthesis of thermally stable high gloss water dispersible polyurethane/polyacrylate resins," Prog. Org. Coatings 76(9), 1135-1143. DOI: 10.1016/j.porgcoat.2013.03.009

Slabejova, G., Šmidriaková, M., and Fekiač, J. (2016). “Gloss of transparent coating on beech wood surface," Acta Facultatis Xylologiae Zvolen 58(2), 37-44. DOI: 10.17423/afx.2016.58.2.04

Sudin, C., Tajuddin, A. A., and Bradley, D. A. (1988). "Evaluation of tissue-equivalent media for dosimetric studies," in: Proceeding of Local Seminar Activities on Radiation Physics, Biophysics and Medical Physics, Kuala Lumpur, Malaysia, pp. 
71-80.

Tousi, E. T., Hashim, R., Bauk, S., Jaafar, M. S., Abuarra, A. M. H., and Ababneh, B. (2014). "Some properties of particleboards produced from Rhizophora spp. as a tissue-equivalent phantom material bonded with Eremurus spp.," Measurement 54, 14-21. DOI: 10.1016/j.measurement.2014.04.004

van Meel, P. A., Erich, S. J. F., Huinink, H. P., Kopinga, K., de Jong, J., and Adan, O. C. G. (2011). "Moisture transport in coated wood," Prog. Org. Coatings 72(4), 686-694. DOI: 10.1016/j.porgcoat.2011.07.011

Vardi, J., Golan, A., Levy, D., and Gilead, I. (2010). "Tracing sickle blade levels of wear and discard patterns: A new sickle gloss quantification method," J. Archaeol. Sci. 37(7), 1716-1724. DOI: 10.1016/j.jas.2010.01.031

Wang, Q., Shen, J., Shen, X., and Du, J. (2018). "Volatile organic compounds and odor emissions from alkyd resin enamel-coated particleboard," BioResources 13(3), 68376849. DOI: 10.15376/biores.13.3.6837-6849

White, D. R., Buckland-Wright, J. C., Griffith, R. V., Rothenberg, L. N., Showwalter, C.K., Williams, G., Wilson, I. J., and Zankl, M. (1992). "Report 48: Phantoms and computational models in therapy, diagnosis and protection," J. Int. Comm. Radiat. Units Meas. DOI: 10.1093/jicru/os25.1.Report48

White, D. R., and Constantinou, C. (1982). "Anthropomorphic phantom materials," in: Progress in Medical Radiation Physics, C. G. Orton (ed.), Plenum Press, New York, pp. 133-193.

Yusof, M. F. M., Hamid, P. N. K. A., Tajuddin, A. A., Abdullah, R., Hashim, R., Bauk, S., Isa, N. M., and Isa, M. J. M. (2017a). "Characterization and attenuation study on tannin-added Rhizophora spp. particleboard at high energy photon and electron," AIP Conference Proceedings 1799(1), Article ID 40002. DOI: 10.1063/1.4972926

Yusof, M. F. M., Hamid, P. N. K. A., Tajuddin, A. A., Hashim, R., Bauk, S., Isa, N. M., and Isa, M. J. M. (2017b). "Fabrication and characterisation of phantom material made of tannin-added Rhizophora spp. particleboards for photon and electron beams," Journal of Physics: Conference Series 51, Article ID 012036. DOI: 10.1088/1742-6596/851/1/012036

Zuber, S. H., Hashikin, N. A. A., Mohd Yusof, M. F., and Hashim, R. (2020). "Physical and mechanical properties of soy-lignin bonded Rhizophora spp. particleboard as a tissue-equivalent phantom material," BioResources 15(3), 5558-5576. DOI: 10.15376/biores.15.3.5558-5576

Article submitted: 27 May 2020; Peer review completed: August 3, 2020; Revised version received and accepted: August 4, 2020; Published; August 7, 2020.

DOI: $10.15376 /$ biores.15.4.7404-7419 